\title{
EGCG, a major green tea catechin suppresses breast tumor angiogenesis and growth via inhibiting the activation of HIF-1 $\alpha$ and NF $\varkappa B$, and VEGF expression
}

\author{
Vascular Cell 5:9 I DOI: 10.1186/2045-824X-5-9 I C Li et al.; licensee Publiverse Online S.R.L. 2013 \\ Received: 29 Jan 2013 | Accepted: 16 Jan 2013 | Published: 2 Jan 2013 \\ Gu Jian-Wei ${ }^{@}$, Makey Kristina L, Tucker Kevan B, Chinchar Edmund, Mao Xiaowen, Pei Ivy, Thomas Emily Y, \\ Miele Lucio \\ ${ }^{+}$Contributed equally ${ }^{@}$ Corresponding author
}

\begin{abstract}
The role of EGCG, a major green tea catechin in breast cancer therapy is poorly understood. The present study tests the hypothesis that EGCG can inhibit the activation of HIF-1 $\alpha$ and NFxB, and VEGF expression, thereby suppressing tumor angiogenesis and breast cancer progression. Sixteen eight-wk-old female mice (C57BL/6 J) were inoculated with $10^{\wedge} 6$ E0771 (mouse breast cancer) cells in the left fourth mammary gland fat pad. Eight mice received EGCG at 50-100 mg/kg/d in drinking water for 4 weeks. 8 control mice received drinking water only. Tumor size was monitored using dial calipers. At the end of the experiment, blood samples, tumors, heart and limb muscles were collected for measuring VEGF expression using ELISA and capillary density (CD) using CD31 immunohistochemistry. EGCG treatment significantly reduced tumor

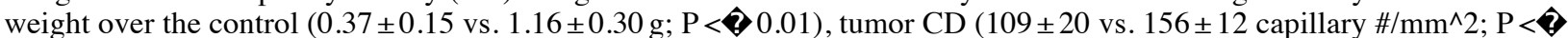
0.01 ), tumor VEGF expression (45.72 \pm 1.4 vs. $59.03 \pm 3.8 \mathrm{pg} / \mathrm{mg} ; \mathrm{P}<0.01)$, respectively. But, it has no effects on the body weight, heart weight, angiogenesis and VEGF expression in the heart and skeletal muscle of mice. EGCG at $50 \mu \mathrm{g} / \mathrm{ml}$ significantly inhibited the activation of HIF- $1 \alpha$ and NFxB as well as VEGF expression in cultured E0771 cells, compared to the control, respectively. These findings support the hypothesis that EGCG, a major green tea catechin, directly targets both tumor cells and tumor vasculature, thereby inhibiting tumor growth, proliferation, migration, and angiogenesis of breast cancer, which is mediated by the inhibition of HIF-1 $\alpha$ and NF $x$ B activation as well as VEGF expression.
\end{abstract}

\section{Introduction}

The term 'green tea' refers to the product manufactured from fresh tea leaves by steaming or drying at elevated temperatures with the precaution to avoid oxidation of the polyphenolic components known as catechins [ 1]. The natural product (-)epigallocatechin-3-gallate (EGCG) accounts for 50-80\% of catechins in green tea, representing 200-300 mg in a brewed cup of green tea [2]. Several other catechins such as (-)-epicatechin-3-gallate (ECG), (-)-epigallocatechin (EGC), and (-)epicatechin (EC) are found in lower abundance in green tea [3]. EGCG is defined as a major green tea catechin that contributes to beneficial therapeutic effects, including anti-oxidant, anti-inflammatory, anti-cancer, and immunomodulatory effects [ 4-6]. Studies conducted on cell-culture systems and animal models as well as human epidemiological studies show that EGCG in green tea could afford protection against a variety of cancer types [ 7]. Many studies have shown that EGCG produces anti-cancer effect by modulating the activity of mitogen-activated protein kinases (MAPKs), IGF/IGF-1 receptor, Akt, NFxB and HIF-1 $\alpha$ [ 8- 12]. A case-control study including 501 breast cancer cases and 594 controls shows that green tea consumption has a significant trend of decreasing risk in a dose-dependent manner, after adjusting for potential confounding factors [ 13]. However, the investigations of green tea or EGCG in breast cancer using animal model are very limited, and the role of EGCG in breast cancer therapy is poorly understood.

The growth and expansion of a tumor is mainly dependent on angiogenesis, the formation of new capillaries from preexisting blood vessels. Avascular tumors are those that do not grow beyond a maximum size of 1 to $2 \mathrm{~mm}^{3}$ in the absence of neovascularization, and it may be eliminated by a normal immune system [ 14]. Angiogenesis requires stimulation of vascular endothelial cells through the release of angiogenic factors. Of these, the vascular endothelial growth factor (VEGF) is the most critical regulator in the development of the vascular system and is commonly overexpressed in a variety of human solid tumors including breast cancer [ 15]. Cancer cells are under greater hypoxia and oxidative stress than normal cells. Oxygen radicals and hypoxia co-operatively promote tumor angiogenesis [ 16]. Hypoxia causes the activation of HIF-1, in which it stimulates VEGF expression. HIF-1 levels are also increased by oxygen radicals. In addition, oxygen radicals activate NFxB that also increases VEGF expression. VEGF is a key angiogenic factor that stimulates the growth of tumors including breast cancer, in which VEGF exerts paracrine (especially angiogenesis) and autocrine (proliferation and migration) effects to promote progression of breast cancer [ 17]. As mentioned above, we believe that EGCG can block highly activated NFXB and HIF-1 $\alpha$ pathways in breast tumor. Therefore, we hypothesizes that EGCG directly targets both of tumor cells and tumor vasculature, thereby inhibiting tumor growth, proliferation, migration, and angiogenesis of breast cancer, which is mediated by the inhibition of HIF- $1 \alpha$ and NFxB activation as well as VEGF expression. Also, EGCG 
treatment has no significant effects on the body weight, heart weight, angiogenesis and VEGF expression in normal tissues such as the heart and skeletal muscle.

To test this hypothesis, the present study aimed to determine the following: (a) whether a relative high oral dose of EGCG inhibits tumor growth, tumor angiogenesis, and VEGF expression in an immunocompetent mouse model (C57BL/6) of breast cancer; (b) whether oral EGCG treatment affects angiogenesis and VEGF expression in normal tissues such as the heart and skeletal muscle in the same mice; and (c) whether EGCG inhibits proliferation, migration, VEGF expression, the activation of HIF- $1 \alpha$ and NFxB in cultured mouse and human breast cancer cells (E0771, MCF-7 and MDA-MB-231).

\section{Materials and methods}

\section{Chemicals and cell lines}

EGCG was purchased from Sigma Chemical Co. (St. Louis, MO). The mouse breast cancer cells (E0771) which were originally isolated from an immunocompetent C57BL/6 mouse, were provided by Dr. Sirotnak FM at Memorial Sloan Kettering Cancer Center, New York, NY [ 18]. Human estrogen-receptor positive breast cancer (MCF-7) cells and human triple negative breast cancer (MDA-MB-231) cells were purchased from the American Type Culture Collection (Rockville, MD). All breast cancer cells were maintained as monolayer cultures in RPMI Medium 1640 (GIBCO) supplemented with $10 \%$ FBS (HyClone), $100 \mathrm{U} / \mathrm{ml}$ penicillin, $100 \mu \mathrm{g} / \mathrm{ml}$ streptomycin, and $0.25 \mu \mathrm{g} / \mathrm{ml}$ amphotericin $\mathrm{B}$, and incubated at $37^{\circ} \mathrm{C}$ in a humidified $5 \% \mathrm{CO}_{2} /$ air injected atmosphere.

\section{Animal protocols}

The protocols were carried out according to the guidelines for the care and use of laboratory animals implemented by the National Institutes of Health and the Guidelines of the Animal Welfare Act and were approved by the University of Mississippi Medical Center's Institutional Animal Care and Use Committee. 16 female C57BL/6 mice at 7 weeks of age were purchased from Jackson Laboratory (Bar Harbor, Maine). The mice were allowed to acclimate for 1 week with standard chaw diet (Teklad, Harlan Sprague Dawley; Indianapolis, IN) and tap water before beginning the experiments. The eight week old female mice $(n=16)$ were inoculated with $10^{\wedge} 6$ E0771 cells suspended in $100 \mu$ l of phosphate-buffered saline into the left fourth mammary gland fat pad. Then, 8 mice received EGCG $(25 \mathrm{mg} / 50 \mathrm{ml})$ in drinking water for 4 weeks and 8 control mice received drinking water only. Each mouse $(20 \mathrm{~g})$ usually drank 2 to $4 \mathrm{ml}$ of water per day. Therefore, EGCG was given around 50 to $100 \mathrm{mg} / \mathrm{kg} /$ day to the mice. The body weight of the mice was monitored weekly. Tumor size was monitored every other day in two perpendicular dimensions parallel with the surface of the mice using dial calipers. At the end of the experiment, blood samples, tumors, heart and limb muscles were collected for measuring VEGF expression using ELISA and average microvascular density (AMVD) or capillary density (CD) using CD31 immunohistochemistry.

\section{Morphometric analysis of angiogenesis in tumor, the heart and limb muscles}

The quantification of blood vessels in mouse breast tumor, the heart and limb muscle was determined with the modification of a previously reported method [ 17, 19]. Briefly, the tissues were fixed in $4 \%$ neutrally buffered paraformaldehyde. For the heart left ventricular and limb muscle samples, consecutive thin transverse cryosections $(5 \mu \mathrm{m})$ were cut along the base-apex axis. Consecutive thin cryosections $(5 \mu \mathrm{m})$ of OCT compound (Sakura Finetek, Torrance, CA) embedded tissue samples were fixed in acetone at $4^{\circ} \mathrm{C}$ for $10 \mathrm{~min}$. After washing in phosphate-buffered saline (PBS), the sections were treated with $3 \% \mathrm{H}_{2} \mathrm{O}$ ${ }_{2}$ for 10 minutes to block endogenous peroxidase activity and were blocked with normal rabbit serum. Then, the sections were washed in PBS and incubated with rat anti-mouse CD31 (PECAM-1) monoclonal antibody (BD Pharmingen, San Diego, CA) at a 1:200 dilution overnight at $4{ }^{\circ} \mathrm{C}$. Negative controls were incubated with the rat serum IgG at the same dilution. All sections were washed in PBS containing $0.05 \%$ Tween-20, and were then incubated with a $2^{\text {nd }}$ antibody, mouse anti-rat IgG (Vector laboratories, Burlingame, CA) at a 1:200 dilution for 1 hour at room temperature again followed by washing with PBS containing $0.05 \%$ Tween-20. The sections were incubated in a 1:400 dilution of Extravadin Peroxidase (Sigma, St. Louis, MO) for $30 \mathrm{~min}$. After washing in PBS containing $0.05 \%$ Tween-20, the sections were incubated in peroxidase substrate (Vector laboratories, Burlingame, CA) for $5 \mathrm{~min}$. The sections were washed in PBS containing $0.05 \%$ Tw een-20 and were counterstained with hematoxylin. A positive reaction was indicated by a brown staining. The microvascular vessels were quantified by manual counting under light microscopy. A microscopic field $\left(0.7884 \mathrm{~mm}^{2}\right)$ was defined by a grid laced in the eye-piece. At least 20 microscopic fields were randomly acquired from each tumor for analysis. Any endothelial cell or cell cluster showing antibody staining and clearly separated from an adjacent cluster was considered to be a single, countable microvessel. The value of average microvascular density (AMVD) or capillary density (CD) was determined by calculating the mean of the vascular counts per $\mathrm{mm}^{2}$ obtained in the microscopic fields for each tissue sample.

\section{Measurements of protein levels of VEGF by ELISA}

Protein levels of VEGF in plasma, breast tumor, the heart, the limb muscle, and the medium cultured with E0771 cells were determined using mouse VEGF ELISA kits (R\&D Systems, Minneapolis, MN), according to the manufacturer's instructions. The total proteins of breast tumor, the heart, the limb muscle, and cultured E0771 cells were extracted using NE-PER Cytoplasmic Extraction Reagents (Pierce, Rockford, IL), according to the manufacturer's protocol. The total protein concentration of these tissue extractions was determined using a Bio-Rad Protein Assay (Bio-Rad Laboratories, Hercules, CA). The protein concentrations of VEGF were normalized and expressed as pictograms per milligram of total tissue or cell extraction protein. 
The E0771, MCF-7, and MDA-MB-231cells were seeded into 6-well tissue culture plates using RPMI Medium 1640 (GIBCO) supplemented with 10\% FBS (HyClone), $100 \mathrm{U} / \mathrm{ml}$ penicillin, $100 \mu \mathrm{g} / \mathrm{ml}$ streptomycin, and $0.25 \mu \mathrm{g} / \mathrm{ml}$ amphotericin $\mathrm{B}$, and incubated at $37^{\circ} \mathrm{C}$ in a humidified $5 \% \mathrm{CO}_{2} /$ air injected atmosphere. When the monolayer reached about $80 \%$ confluence, the cells were washed with PBS and incubated with fresh RPMI Medium 1640 with $10 \%$ FBS in the absence and presence of EGCG $(0,10,50 \mu \mathrm{g} / \mathrm{ml})$ for 18 hours. $3 \mathrm{H}$-thymidine incorporation assay was used to determine the cell proliferation during the last 6 hours of incubation as previously described [ 20].

\section{Migration assay}

Migration was determined using BD BioCoat Matrigel Invasion Chamber (BD Bioscience Discovery Labware, Sedford, MA) according to a previous study, in which only invasive cells digested the matrix and moved through the insert membrane [ 21]. $1 \times 10^{5}$ E0771 cells per well in $0.5 \mathrm{ml}$ medium (RPMI Medium 1640) were seeded in the matrigel-coated upper compartment (insert) of a Transwell (24-well format, 8 - $\mu \mathrm{m}$ pore) in the absence of and presence of EGCG $(0,10,20,50 \mu \mathrm{g} / \mathrm{ml})$ and the medium with $10 \% \mathrm{FBS}$ was added to the lower part of the well. After overnight incubation at $37^{\circ} \mathrm{C}$ and $5 \% \mathrm{CO}{ }_{2}$, cells on the upper surface of the insert were removed using a cotton wool swab. Migrated cells on the lower surface of the insert were stained using DiffQuit (Dada Behring, Düdinen, Switzerland). The images of migrated cells were taken and the number of migrated cells was counted using a microscope (Leica, Germany) in a 20× objective.

\section{HIF-1 $\alpha$ and NF $\varkappa B$ activation (motif binding) assays}

We determined HIF- $1 \alpha$ and NFxB activation in cultured E0771 cells in the absence and presence of EGCG $(0 \mathrm{and} 50 \mathrm{mg} / \mathrm{ml})$ to investigate whether the down-regulation of VEGF by EGCG is associated with the inhibition of HIF- $1 \alpha$ and NF $\mathcal{B}$ activation $(n=6)$. The nuclear proteins were extracted by using Active Motif (Carlsbad, CA) nuclear extract kit. $20 \mu \mathrm{g}$ nuclear proteins from each sample was used in the TransAM HIF-1 $\alpha$ or NFxB p65 kit (Active Motif), which can measure the binding of activated HIF- $1 \alpha$ or NF $x$ B to its consensus sequence attached to a microwell plate, according the manufacturer's instructions.

\section{Statistical analysis}

All determinations were performed in duplicated sets. Where indicated, data is presented as mean \pm SE. Statistically significant differences in mean values between the two groups were tested by an unpaired Student's t-test. Linear regression was performed by the correlation analysis between two continuous variables. A value of $\mathrm{P}<0.05$ was considered statistically significant. All statistical calculations were performed using SPSS software (SPSS Inc., Chicago, IL).

\section{Results}

\section{A relative high oral dose of EGCG significantly inhibits the progression of breast cancer growth}

We used a mouse breast cancer model that mimics the human disease, in which the mouse breast adenocinoma (E0771) cells were injected into the pad of the fourth mammary gland of female immunocompetent mice (C57BL/6). Immediately after the inoculation of E0771 cells, the eight week old female mice $(n=8)$ were given EGCG at 50 to $100 \mathrm{mg} / \mathrm{kg} / \mathrm{day}$ in drinking water for four weeks and the control group $(n=8)$ was given regular drinking water only. Tumor size was then monitored every other day in two perpendicular dimensions parallel with the surface of the mice using dial calipers. As indicated in Figure $1 \mathrm{~A}$, the tumor cross section area was significantly reduced in the EGCG-treated group compared to the control group two weeks after the breast cancer inoculation. At the end of experiment, the tumor cross section area was reduced by $65 \%(\mathrm{P}$ $<0.01$ ) in EGCG-treated group compared to the control group (Figure 1 A), which was consistent with the reduction in tumor weight (Figure 1 B) in EGCG-treated group compared to the control group $(0.37 \pm 0.15$ vs. $1.16 \pm 0.30 \mathrm{~g}$; P $<0.01)$. Clearly, EGCG treatment at 50 to $100 \mathrm{mg} / \mathrm{kg} / \mathrm{d}$ in drinking water significantly inhibited the progression of breast cancer growth in the female mice by decreasing the tumor size and reducing the growth curve of breast cancer. However, there was no significant difference in the body weight, heart weight, kidney weight, or urinary protein between the EGCG-treated mice and the control mice.

\section{Figure 1}




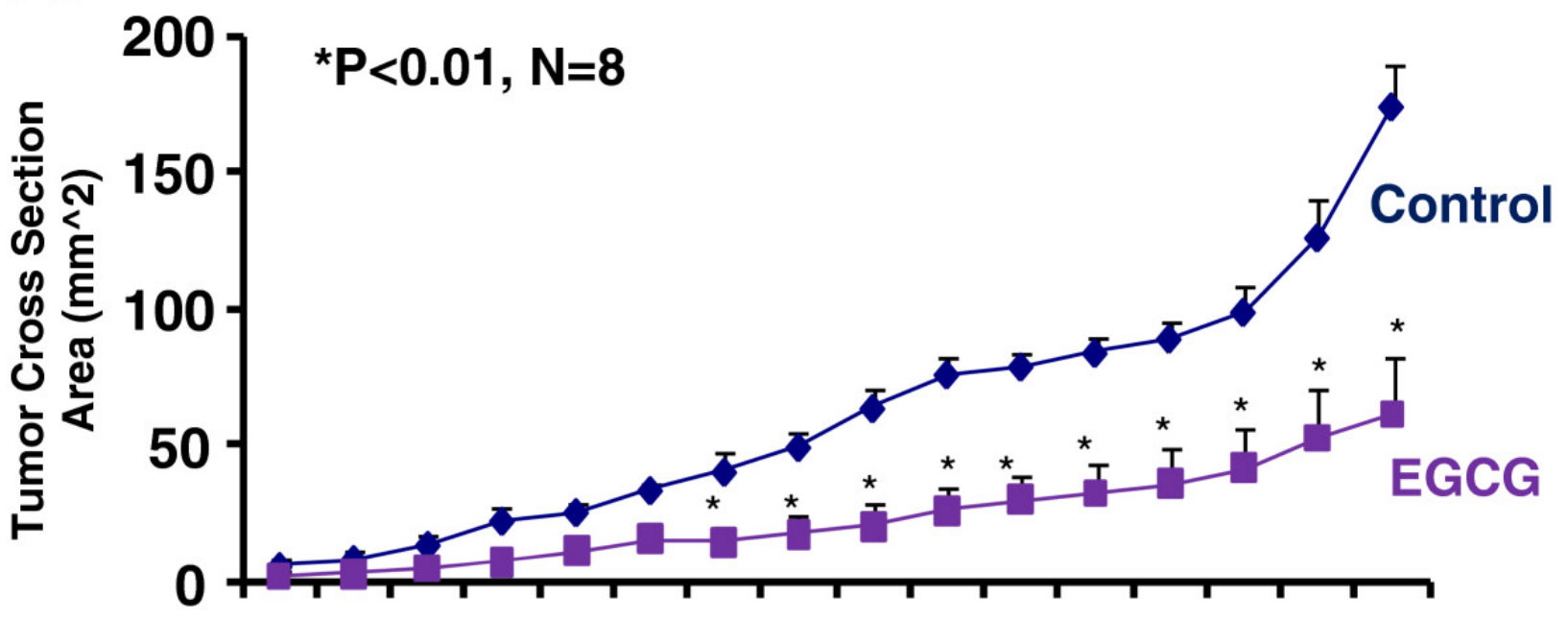

9101112131415161718192021222324 (days)

B

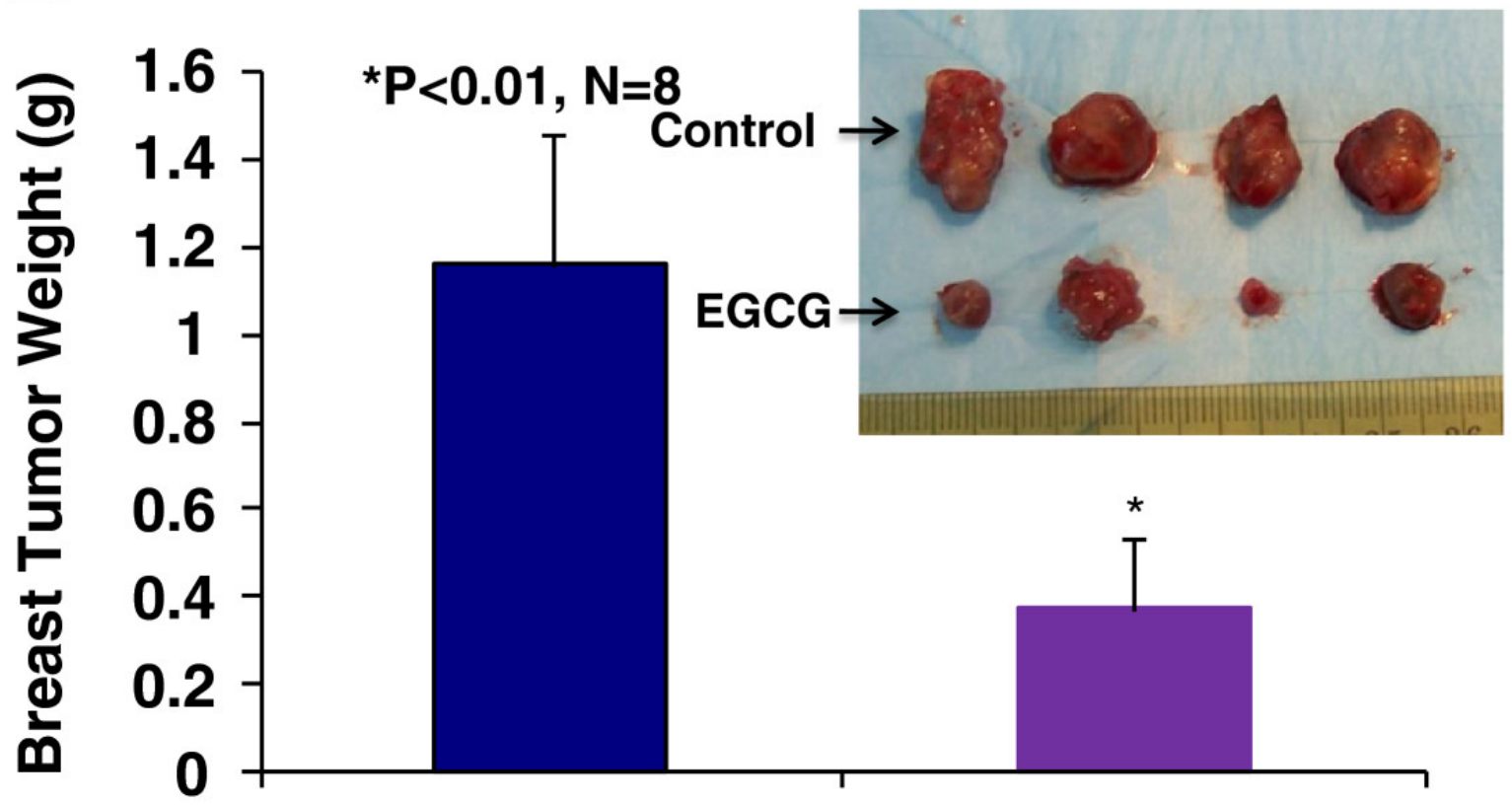

Control

EGCG

The inhibition of the progression of breast cancer growth by oral EGCG in the immunocompetant female mice (C57BL/6) allografted with mouse breast cancer (E0771) cells.EGCG at 50 to $100 \mathrm{mg} / \mathrm{kg} / \mathrm{day}$ in drinking water for four weeks significantly reduced a growth curve of breast cancer monitored by the tumor cross section area by $65 \%$ (Figure $1 \mathrm{~A}, \mathrm{P}<$ $0.01 ; \mathrm{n}=8$ ) and tumor weight (Figure $1 \mathrm{~B}, 0.37 \pm 0.15 \mathrm{vs} .1 .16 \pm 0.30 \mathrm{~g} ; \mathrm{P}<0.01 ; \mathrm{n}=8$ ), compared to the control group.

\section{EGCG suppresses breast tumor angiogenesis and VEGF expression in mice}

Growth and expansion of tumor mass are strictly dependent on angiogenesis because neovascularization permits rapid tumor growth by providing an exchange of nutrients, oxygen, and paracrine stimuli to the tumor [22]. Therefore, in this study, we used a morphometric analysis of immunohistochemical staining for CD31 to determine the effect of EGCG on breast tumor angiogenesis in mice. Representative images of CD31 staining of the breast cancer tumors showed that the EGCG-treated tumor had lesser microvessels than the control tumor (Figure $2 \mathrm{~A}$ ). Morphometric analysis (Figure $2 \mathrm{~A}$ ) indicated that PDTC treatment caused a significant decrease in average microvessel density (AMVD, the number of microvessels per mm2 area) of breast tumors compared to the control breast tumors ( $109 \pm 20$ vs. $156 \pm 12$ microvessels number per $\mathrm{mm}^{\wedge} 2 ; \mathrm{n}=8 ; \mathrm{P}<$ $0.01)$. These results also suggest that a pronounced decrease in tumor angiogenesis is associated with a decrease in tumor size of breast cancer tumor in the female mice treated with EGCG compared to those in the control mice. Figure $2 \mathrm{~B}$ also demonstrated that EGCG treatment reduced plasma VEGF levels over the control mice $(26.48 \pm 3.76 \mathrm{vs} .40 .79 \pm 3.5 \mathrm{pg} / \mathrm{ml} ; \mathrm{n}$ $=8 ; \mathrm{P}<0.01)$ and tumor VEGF expression over the control mice $(45.72 \pm 1.4$ vs. $59.03 \pm 3.8 \mathrm{pg} / \mathrm{mg} ; \mathrm{n}=8 ; \mathrm{P}<0.01)$. These findings suggest that the inhibition of tumor angiogenesis in mice by EGCG is due to the down-regulation of VEGF because VEGF is a key angiogenic factor. 

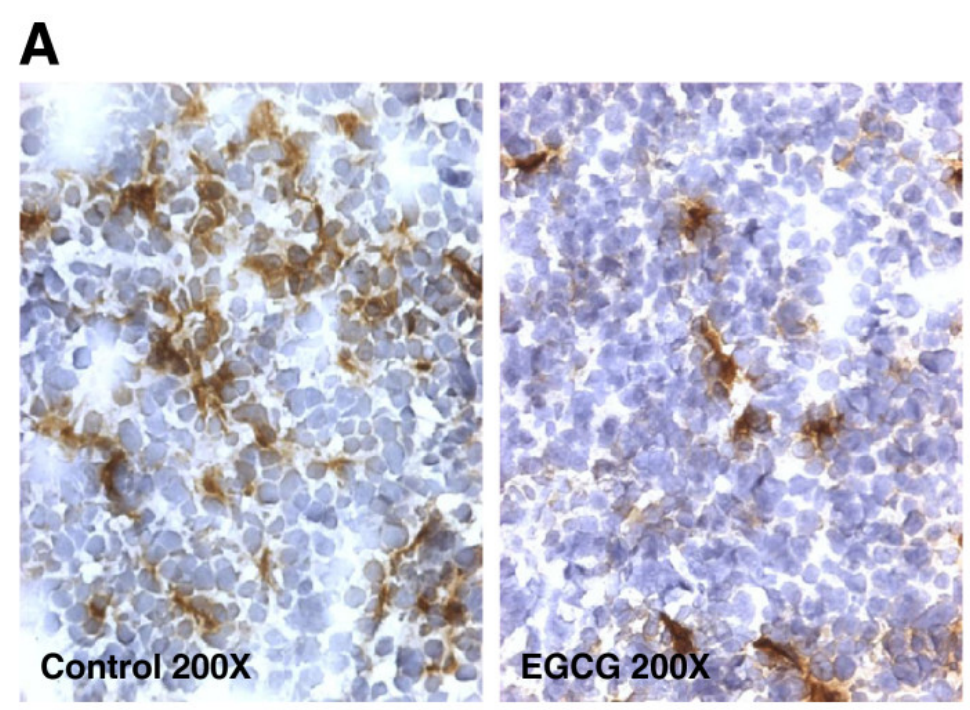

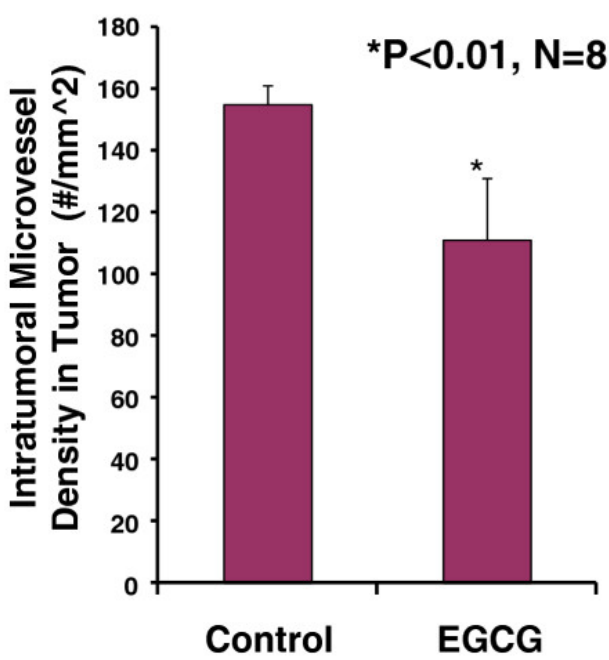

B
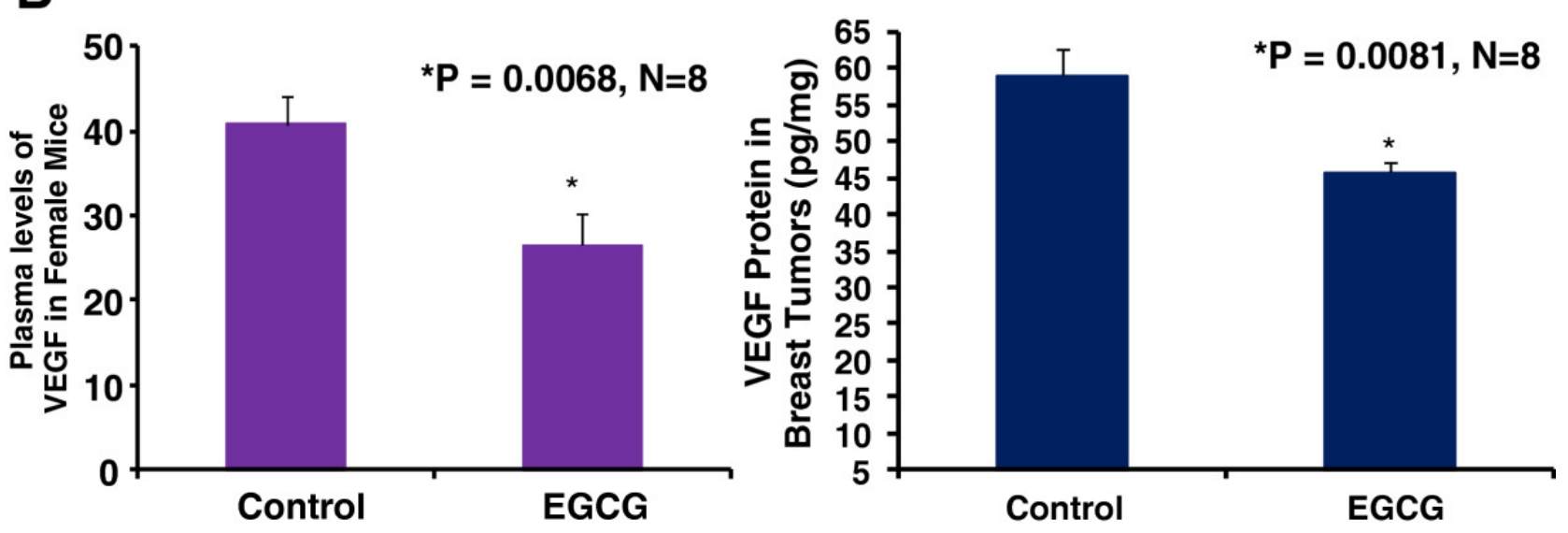

Oral EGCG at $50-100 \mathrm{mg} / \mathrm{kg} / \mathrm{d}$ in drinking water significantly reduced intratumoral microvessel density (Panel A: $109 \pm$ 20 vs. $156 \pm 12$ microvessel \#/mm^2; $\mathrm{P}<0.01$ ), plasma VEGF levels (Panel B; $26.48 \pm 3.76$ vs. 40.79 $\pm 3.5 \mathrm{pg} / \mathrm{ml} ; \mathrm{P}<$ 0.01 ), and tumor VEGF expression (Panel B; $45.72 \pm 1.4 \mathrm{vs} .59 .03 \pm 3.8 \mathrm{pg} / \mathrm{mg} ; \mathrm{P}<0.01$ ) over the control, respectively in mice $(n=8)$. The digital images show CD31 immunohistochemistry staining in OCT-embedded cryosections of mouse breast cancer tumors obtained from a control (Figure 2A) or EGCG-treated (Figure 2A) mouse.

\section{EGCG directly inhibits proliferation and migration of breast cancer cells}

We used a $3 \mathrm{H}$-thymidine incorporation assay to determine the effects of EGCG on the proliferation of cultured mouse breast cancer cells (E0771), human estrogen receptor positive breast cancer cells (MCF-7), and triple negative breast cancer cells (MDA-MB-231). Figure $3 \mathrm{~A}$ showed that E0771 cells treated with EGCG caused a dose-related decrease in 3H-thymidine incorporation, decreasing by $22 \%$ at $10 \mu \mathrm{g} / \mathrm{ml}$ and by $77 \%$ at $50 \mu \mathrm{g} / \mathrm{ml}$, compared to the control group $(\mathrm{n}=6 ; \mathrm{P}<0.01)$. We examined the inhibitory effect of EGCG on E0771 cell migration using BD BioCoat Matrigel Invasion Chamber. Figure 3 B demonstrates that EGCG at 10,20, and $50 \mu \mathrm{g} / \mathrm{ml}$ caused a dose-dependent reduction of migrated breast cancer (E0771) cells, decreasing by $25 \%, 48 \%$, and $71 \%$, respectively, compared to the control group $(n=6 ; \mathrm{P}<0.01)$. In the another experiment, as shown in Figure $3 \mathrm{C}$, we demonstrated that EGCG at $50 \mu \mathrm{g} / \mathrm{ml}$ significantly inhibited the proliferation of human estrogen receptor positive breast cancer cells (MCF-7) and triple negative breast cancer cells (MDA-MB-231) by $91 \%$ and $52 \%$, respectively, compared to the control group $(\mathrm{n}=6 ; \mathrm{P}<0.01)$, but not at $10 \mu \mathrm{g} / \mathrm{ml}$. These in vitro findings illustrate that EGCG can directly target breast cancer cells by inhibiting the proliferation and migration.

Figure 3 
A

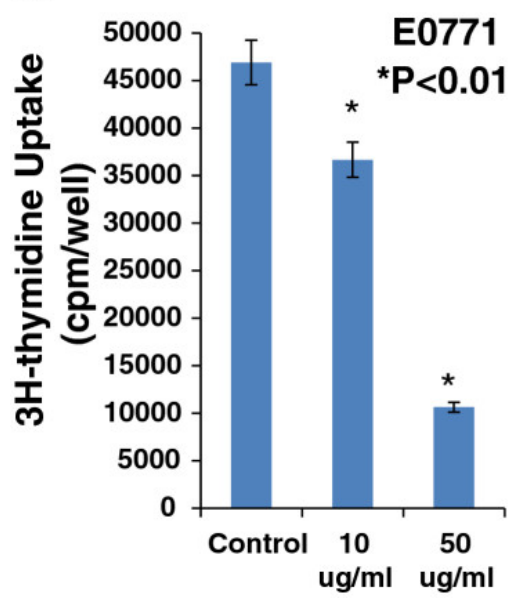

B

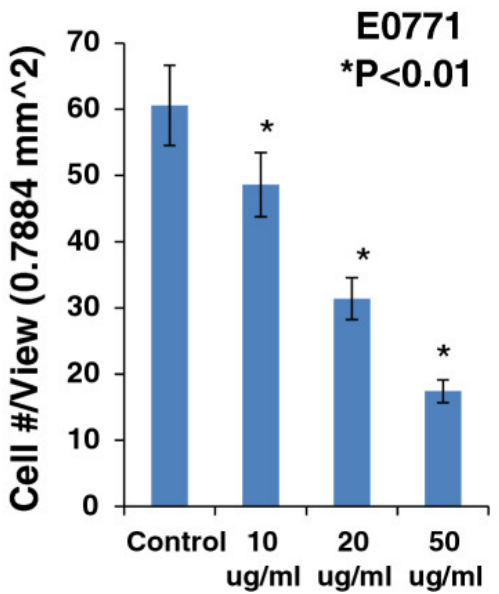

C

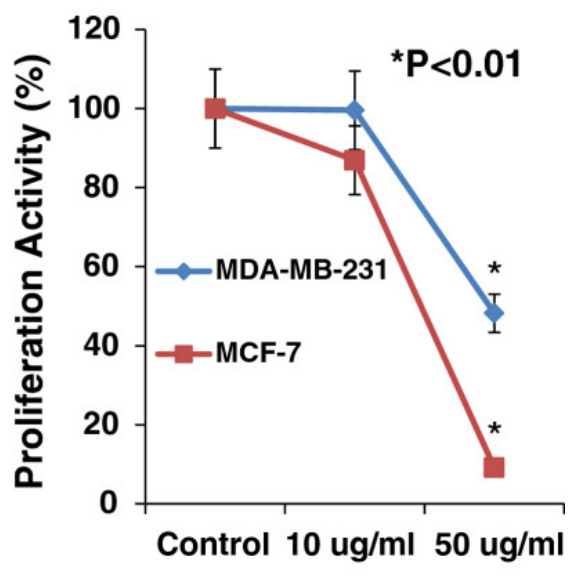

EGCG caused a dose-related inhibition in 3H-thymidine incorporation, decreasing by $22 \%$ at $10 \mu \mathrm{g} / \mathrm{ml}$ and by $77 \%$ at 50 $\mu \mathrm{g} / \mathrm{ml}$ (Panel A, $\mathrm{n}=6, \mathrm{P}<0.01$ ), and in migration (Panel $\mathrm{B}, \mathrm{n}=6, \mathrm{P}<0.01$ ) in cultured E0771 cells, compared to the control group.In Panel C, EGCG at $50 \mu \mathrm{g} / \mathrm{ml}$ significantly inhibited the proliferation in cultured MCF-7 and MDA-MB231 cells, compared to the control group $(n=6 ; P<0.01)$, respectively.

The down-regulation of VEGF expression by EGCG is associated with the inhibition of HIF-1 $\alpha$ and $\mathrm{NF} \varkappa \mathrm{B}$ activation

HIF-1 and NFxB pathways are highly activated in breast tumor, in which they can co-operatively promote tumor angiogenesis by increasing VEGF expression [ 16]. We used VEGF ELISA kit and HIF-1 $\alpha$ and NFxB activation (Motif Binding) assays to determine whether EGCG could suppress HIF-1 $\alpha$ and NF $x$ B activation and VEGF expression in cultured mouse breast cancer (E0771) cells. Figure 4A showed that EGCG at $50 \mu \mathrm{g} / \mathrm{ml}$ significantly inhibited VEGF expression $(1752 \pm 49$ vs. $2254 \pm 91 \mathrm{pg} / \mathrm{mg} ; \mathrm{n}=6 ; \mathrm{P}<0.01)$ in cultured E0771 cells, compared to the control. In the same experiment, EGCG at $50 \mu \mathrm{g} / \mathrm{ml}$ also significantly suppressed the activation of HIF- $1 \alpha(0.11 \pm 0.02$ vs. $0.24 \pm 0.02 ; \mathrm{P}<0.01$; Figure 4B) and NFxB $(1.15 \pm 0.21$ vs. $1.61 \pm 0.32 ; n=6 ; \mathrm{P}<0.01$; Figure $4 \mathrm{C})$, compared to the control, respectively. These results suggest that the inhibition of HIF-1 $\alpha$ and NFxB activation contributes to the down-regulation of VEGF expression.

Figure 4
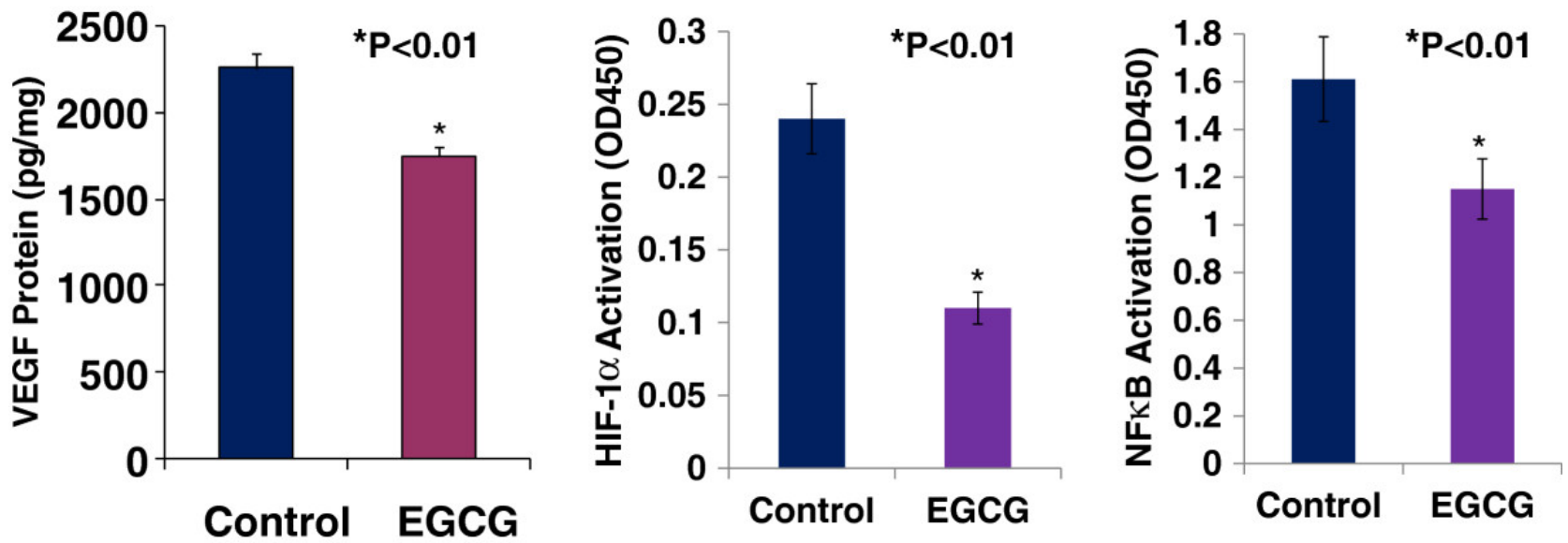

EGCG at $50 \mu \mathrm{g} / \mathrm{ml}$ significantly inhibited VEGF expression (Panel A, $1752 \pm 49$ vs. $2254 \pm 91 \mathrm{pg} / \mathrm{mg}, \mathrm{n}=6, \mathrm{P}<0.01$ ), the activation of HIF- $1 \alpha$ (Panel B, $0.11 \pm 0.02$ vs. $0.24 \pm 0.02, \mathrm{n}=6, \mathrm{P}<0.01)$ and NF $\mathrm{B}$ (Panel $\mathrm{C}, 1.15 \pm 0.21$ vs. $1.61 \pm 0.32 ; \mathrm{n}=$ $6, \mathrm{P}<0.01)$ in cultured E0771 cells, compared to the control, respectively.

Oral EGCG treatment has no effects on angiogenesis and VEGF expression in normal tissues such as the heart and skeletal muscle in mice

The data showed that there was no significant difference in the body weight $(22.38 .25 \pm 0.51$ vs. $22.94 \pm 0.57 ; \mathrm{n}=8 ; \mathrm{P}=$ $0.9437)$, heart weight $(84.7 \pm 11.2$ vs. 85.1 vs. $10.6 \mathrm{mg} ; \mathrm{n}=8 ; \mathrm{P}=0.3546)$, or kidney weight $(237.5 \pm 9.2$ vs. $240.1 \pm 8.9 \mathrm{mg} ; \mathrm{n}$ $=8 ; \mathrm{P}=0.3735)$ between the EGCG-treated mice and the control mice. Figure $5 \mathrm{~A}$ showed that EGCG treatment did not affect the capillary density (number of capillary $/ \mathrm{mm}^{\wedge} 2$ area) $\left(3270 \pm 162 \mathrm{vs} .3103 \pm 226 \# / \mathrm{mm}^{\wedge} 2 ; \mathrm{n}=8 ; \mathrm{P}=0.5215\right)$ analyzed by CD31 immunochemistry and morphometric analysis, and VEGF expression (261 \pm 22 vs. $245 \pm 19 \mathrm{pg} / \mathrm{mg} ; \mathrm{n}=8 ; \mathrm{P}=$ $0.4517)$ determined by ELISA in the mouse heart, compared to the control group, respectively. Figure $5 \mathrm{~B}$ showed that there was no significant difference in the capillary density ( $\left.370 \pm 55 \mathrm{vs.} 381 \pm 44 \# / \mathrm{mm}^{\wedge} 2 ; \mathrm{n}=8 ; \mathrm{P}=0.5401\right)$, and VEGF expression $(225 \pm 16$ vs. $214 \pm 20 \mathrm{pg} / \mathrm{mg} ; \mathrm{n}=8 ; \mathrm{P}=0.7825)$ in the limb skeletal muscles between the EGCG-treated mice and the control mice, respectively. These findings illustrate that EGCG does not significantly affect angiogenesis and VEGF expression in the normal tissues such as the heart and skeletal muscles. 
A
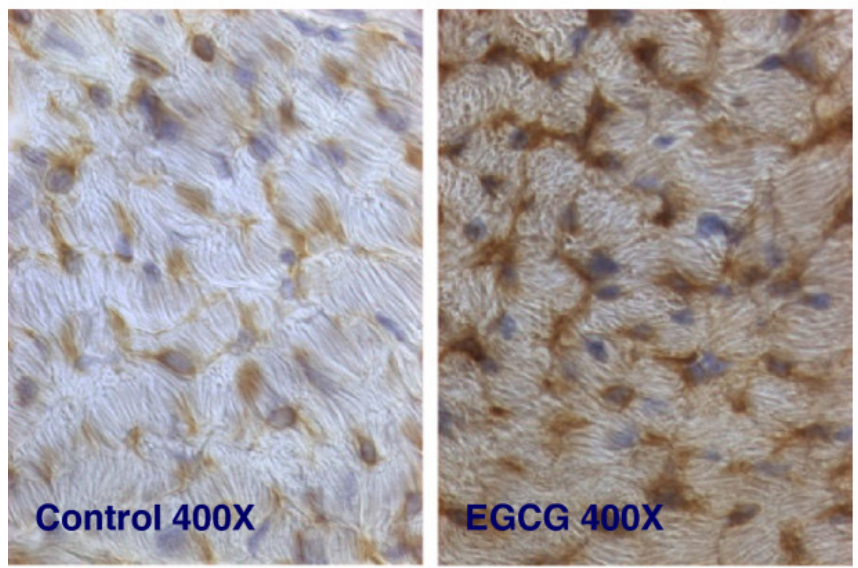

B
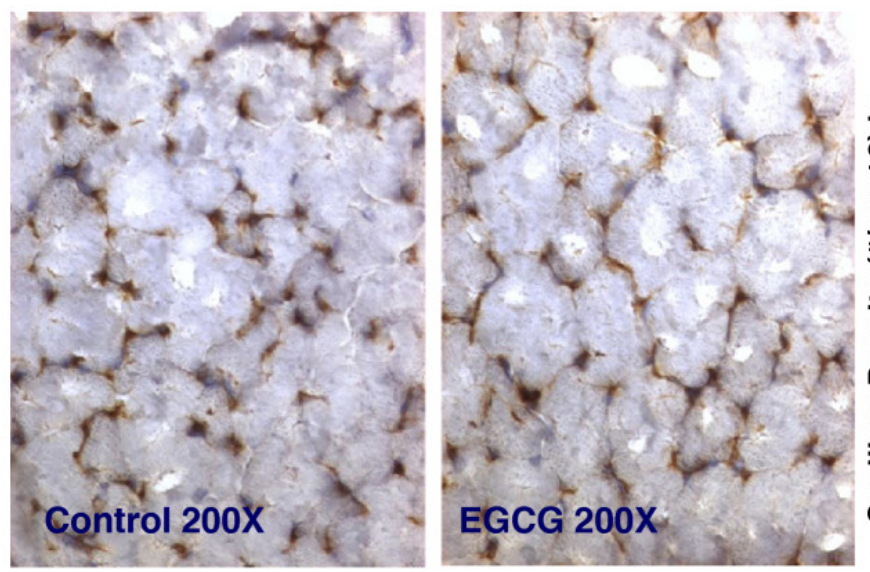
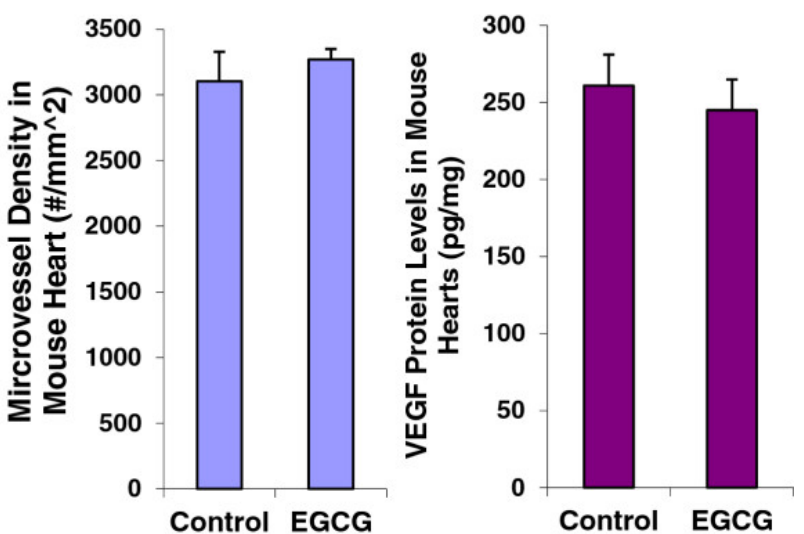
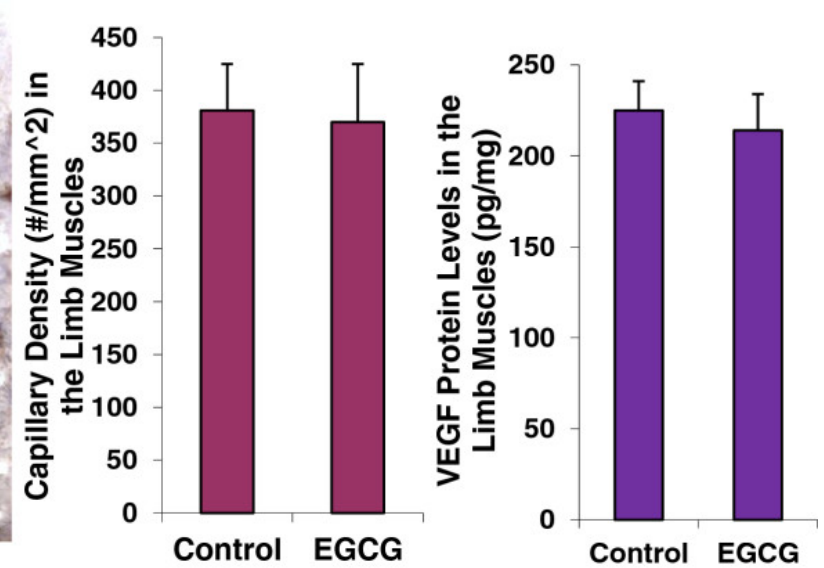

EGCG treatment did not affect the capillary density (3270 \pm 162 vs. $\left.3103 \pm 226 \# / \mathrm{mm}^{\wedge} 2 ; \mathrm{n}=8 ; \mathrm{P}=0.5215\right)$, and VEGF expression $(261 \pm 22$ vs. $245 \pm 19 \mathrm{pg} / \mathrm{mg} ; \mathrm{n}=8 ; \mathrm{P}=0.4517)$ in the mouse heart, compared to the control group (Panel A), respectively.There was no significant difference in the capillary density $\left(370 \pm 55\right.$ vs. $\left.381 \pm 44 \# / \mathrm{mm}^{\wedge} 2 ; \mathrm{n}=8 ; \mathrm{P}=0.5401\right)$, and VEGF expression $(225 \pm 16$ vs. $214 \pm 20 \mathrm{pg} / \mathrm{mg} ; \mathrm{n}=8 ; \mathrm{P}=0.7825)$ in the limb skeletal muscles between the EGCGtreated mice and the control mice (Panel B), respectively. The digital images show CD31 immunohistochemistry staining in OCT-embedded cryosections of the heart (Panel A) and the limb muscle (Panel B) of control mouse and EGCG-treated mouse, respectively.

\section{Discussion}

The major new findings from this study include: 1) a relative high oral dose of EGCG significantly inhibits the progression of mouse breast cancer growth in female immunocompetent mice; 2) EGCG significantly suppresses breast tumor angiogenesis and VEGF expression in these mice; 3) EGCG treatment does not significantly affect angiogenesis and VEGF expression in the normal tissues such as the he art and skeletal muscles in the same experiment; 4) EGCG directly inhibits proliferation and migration of cultured mouse and human breast cancer cells; and 5) the down-regulation of VEGF expression by EGCG is associated with the inhibition of HIF- $1 \alpha$ and NFxB activation. These findings support the hypothesis that EGCG, a major green tea catechin directly targets both of tumor cells and tumor vasculature, thereby inhibiting tumor growth, proliferation, migration, and angiogenesis of breast cancer, which is mediated by the inhibition of HIF-1 $\alpha$ and NFxB activation as well as VEGF expression. Also, EGCG treatment has no significant effects on angiogenesis and VEGF expression in normal tissues such as the heart and skeletal muscle.

An important finding of this study is that a relative high oral dose of EGCG treatment at 50 to $100 \mathrm{mg} / \mathrm{kg} / \mathrm{day}$ in drinking water significantly slows a growth curve of breast cancer in C57BL/6 female mice compared to the control group, which is characterized by $65 \%$ and $68 \%$ reduction in the tumor cross section area and tumor weight, respectively. Clearly, oral EGCG treatment is very effective in suppressing progression of breast cancer in a wild type immunocompetent mouse model. Ullmann et al. reported that peak plasma concentrations were greater than $3 \mu \mathrm{g} / \mathrm{ml}$ after oral dose of $1600 \mathrm{mg}$ in healthy human subjects [23]. We believe that oral dose of 50 to $100 \mathrm{mg} / \mathrm{kg} /$ day in human can reach the effective plasma concentrations of EGCG against breast cancer. Recent methods developed for the stereoselective total synthesis of EGCG, and structurally related catechins, could provide new sources of these compounds for biomedical use [ 24]. Our next step is clinical trial for EGCG in breast cancer therapy.

Cancer cells are under greater hypoxia and oxidative stress than normal cells. 8-hydroxy-2'-deoxyguanosine, a major marker of constitutive oxidative stress is almost 10 times more prevalent in invasive ductal breast carcinoma cells than in normal 
control samples from the same patient [25]. Tumor cells overproduce reactive oxygen species (ROS) by alterations to metabolic pathways in tumor cells [26], an inadequate tumor vascular network [ 16], and macrophage infiltration of the tumor [27]. Breast carcinomas support their growth by stimulating angiogenesis. Blood flow within these new vessels is often chaotic, causing periods of hypoxia followed by reperfusion. The generation of ROS by reperfusion further causes oxidative stress within breast carcinomas. Also, a breast carcinoma rapidly outgrows its blood supply, leading to glucose deprivation and hypoxia. Glucose deprivation rapidly induces oxidative stress within breast carcinoma cells [ 28]. Clearly, hypoxia and oxidative stress are found together within the breast carcinoma, in which VEGF production can be augmented by synergy between oxygen radicals and tumor hypoxia. Oxygen radicals and hypoxia co-operatively promote tumor angiogenesis [ 16]. Hypoxia causes the activation of HIF-1, in which it stimulates VEGF expression. HIF-1 levels are also increased by oxygen radicals. In addition, oxygen radicals activate NFxB that also increases VEGF expression. Thus, the compound blocking HIF-1and NFxB pathways can significantly inhibit VEGF expression and angiogenesis in carcinomas including breast carcinomas.

In this study, we found that the significant inhibitions of tumor growth and tumor angiogenesis of breast cancer in female mice by EGCG were associated with suppressing the activation of HIF-1 $\alpha$ and NFxB, and decreasing VEGF expression in breast carcinoma cells. VEGF is a key angiogenic factor that stimulates the growth of tumors including breast cancer, in which VEGF exerts paracrine (especially angiogenesis) and autocrine (proliferation and migration) effects to promote progression of breast cancer [ 17]. VEGF overexpression and the activation of HIF-1 $\alpha$ and NFxB pathways in breast cancer are strongly linked to rapid growth of tumors and worse prognosis [ 16, 29, 30]. Oxygen radicals and hypoxia co-operatively promote tumor angiogenesis, in which VEGF overexpression is stimulated by the activation of HIF-1 $\alpha$ and NFxB pathways in breast cancer [16]. The present findings indicate that EGCG significantly inhibits VEGF expression by suppressing the activation of HIF- $1 \alpha$ and NFxB pathways, thereby inhibiting tumor growth, proliferation, migration, and angiogenesis of breast cancer. Our results are supported by the previous findings as follows: 1) EGCG suppressed tumor growth by blocking the induction of VEGF in human colon carcinoma cells [ 31]; 2) EGCG inhibited VEGF/VEGFR axis by suppressing the expression of HIF-1 $\alpha$ in human colorectal cancer cells [ 32]; and 3) EGCG inhibited cancer progression by decreasing NFxB activation [33]. Progression stage is the final phase of cancer development, an uncontrolled growth of cancer cells occurs. In this stage cancer cells are under greater hypoxia and oxidative stress, in which many transcription factors, such as HIF-1 $\alpha$ and NFxB, are activated leading to transmit aberrant signals resulting in abnormal functions such as tumor angiogenesis, cancer invasiveness and metastasis. Present findings illustrate that EGCG can inhibit multiple key cellular signals resulting in inhibiting tumor angiogenesis and breast cancer progression. Also, accumulating evidence shows that EGCG can target all stages of cancer development by blocking multiple cellular proteins involved in diverse cellular signal transduction pathways: proliferation, differentiation, apoptosis, angiogenesis or metastasis [ 34]. In future study, we will investigate the therapeutic potentials of EGCG combined with VEGF receptor inhibitor, Notch inhibitor, HIF-1 inhibitor, or NFxB blocker in breast cancer therapy.

In present study, we demonstrated that EGCG treatment reduced plasma VEGF levels by 35\% over the control mice, which was associated with more than $65 \%$ reduction of tumor weight in EGCG treated breast cancer mice, compared to untreated breast cancer mice. These findings are consistent with breast cancer patients that EGCG treatment reduced serum levels of VEGF [ 35]. A study on 200 women showed that serum VEGF levels were significantly higher in breast cancer patients compared to control [ 36]. Systemic VEGF levels were reduced significantly in the breast cancer patients following tumor excision [ 36]. We believe that oral EGCG treatment could reduce the tumor-related blood VEGF levels.

Interestingly, the present study shows that EGCG treatment does not significantly affect angiogenesis and VEGF expression in the normal tissues such as the heart and skeletal muscles in the same experiment. The present study first time shows that oral EGCG treatment significantly inhibits angiogenesis, VEGF expression, and growth in breast tumor, but no such effects on the normal tissues such as the heart and limb muscles in the same mice. The different effects of EGCG in tumor and normal tissues can be explained by that cancer cells are under greater hypoxia and oxidative stress than normal cells. VEGF expression and angiogenesis are very stable in normal matured tissues in which they are regulated by metabolic balance within the tissue. However, angiogenesis is stimulated by significantly increased VEGF levels, activated HIF-1 $\alpha$ and NF $x \mathrm{~B}$ pathways in cancer. We also found that there was no significant difference in the body weight, heart weight, or kidney weight between EGCG-treated mice and the control mice. This is an exciting possibility, because EGCG is a drug of low toxicity.

Antiangiogenic therapy is an attractive approach for cancer treatment including breast cancer, in which these agents include monoclonal antibodies (mAbs) and the tyrosine kinase inhibitors (TKIs) of VEGF pathway. Implicated in many physiological processes, VEGF pathway inhibition can lead to on-target side effects, such as hypertension, proteinuria, thromboembolic events, or congestive heart failure [ 37-39]. The incidence of hypertension rate was up to $35 \%$ with bevacizumab, a monoclonal antibody against VEGF-A [ 40,41]. Ultimately, considering the modest clinical benefit on the one hand, and the increase in toxicity on the other, the US Food and Drug Administration withdraw its approval of the breast cancer treatment for bevacizumab [ 42]. As mentioned above, EGCG is a drug of low toxicity, and significantly inhibits angiogenesis in breast tumor (under greater oxidative stress), but not in the normal tissues (no oxidative stress) such as the heart and limb muscles in the same mice. Thus, EGCG may overcome the existing barriers - the mAbs and TKIs of VEGF pathway-induced ontarget side effects. However, the further studies are needed.

In conclusion, our results indicate that oral administration of EGCG, a major green tea catechin, significantly inhibits tumor growth and tumor angiogenesis of breast cancer, but no effect on angiogenesis in the heart and limb muscles in an immunocompetent mouse model using mouse breast cancer (E0771) cells. EGCG directly suppresses the proliferation or migration of cultured mouse breast cancer cells as well as the proliferation of human breast cancer cells (MCF-7 and MDAMB-231). These anticancer effects of EGCG seem to be mediated by blocking multiple intracellular signaling cascades such as HIF-1 $\alpha$ and NFxB pathways. The mechanistic advance of EGCG on inhibiting tumor angiogenesis is very unique, in which EGCG does not target angiogenesis in normal tissue. Accumulating evidence indicates that EGCG displays a vast array of cellular effects involved in all stages of cancer development. The multiple targets on cancer and less side effects of EGCG will lead a successful targeted therapy for cancers including breast cancer. The potential therapeutic targets of EGCG in cancer therapy are needed to be further explored. Our next step is clinical trial for EGCG in breast cancer therapy. The 


\section{Declarations}

\section{Acknowledgment}

This work was supported by the National Institute on Alcohol Abuse and Alcoholism Grant AA-013821 and the National Heart, Lung, and Blood Institute Grant HL-51971, and research fund from University of Mississippi Cancer Institute.

\section{Authors' original submitted files for images}

Below are the links to the authors' original submitted files for images.

Authors' original file for figure 1

Authors' original file for figure 2

Authors' original file for figure 3

Authors' original file for figure 4

Authors' original file for figure 5

\section{Competing interests}

The authors declare that they have no competing interests.

\section{Authors' contributions}

JG prepared the manuscript and all figures. KM did the animal studies. KT measured capillary density using CD31 immunohistochemistry. EC performed ELISA and proliferation assays. XM prepared discussion for the manuscript. IP worked on migration assay. ET did HIF- $1 \alpha$ and NF $x$ B activation assays. LM edited the final manuscript. All authors read and approved the final manuscript.

\section{References}

1. Butt MS, Sultan MT. Green tea: nature's defense against malignancies. Crit Rev Food Sci Nutr. 2009;49:463-473. View Article Google Scholar

2. Qin J, Xie LP, Zheng XY, Wang YB, Bai Y, Shen HF. A component of green tea, (-)-epigallocatechin-3-gallate, promotes apoptosis in T24 human bladder cancer cells via modulation of the PI3K/Akt pathway and Bcl-2 family proteins. Biochem Biophys Res Commun. 2007;354:852-857.

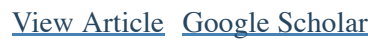

3. Bettuzzi S, Brausi M, Rizzi F, Castagnetti G, Peracchia G, Corti A. Chemoprevention of human prostate cancer by oral administration of green tea catechins in volunteers with high grade prostate intraepithelial neoplasia: a preliminary report from a one-year proof-of-principle study. Cancer Res. 2006;66:1234-1240.

$\underline{\text { View Article Google Scholar }}$

4. Fong HH. Integration of herbal medicine into modern medical practices: issues and prospects. Integr Cancer Ther. 2002;1:287-293.

View Article $\underline{\text { Google Scholar }}$

5. Huffman MA. Animal self-medication and ethno-medicine: exploration and exploitation of the medicinal properties of plants. Proc Nutr Soc. 2003;62:371-381.

View Article Google Scholar

6. Miller KL, Liebowitz RS, Newby LK. Complementary and alternative medicine in cardiovascular disease: a review of biologically based approaches. Am Heart J. 2004;24:703-710.

View Article $\underline{\text { Google Scholar }}$

7. Khan N, Afaq F, Saleem M, Ahmad N, Mukhtar H. Targeting multiple signaling pathways by green tea polyphenol (-)-epigallocatechin-3-gallate. Cancer Res. 2006;66:2500-2505.

View Article Google Scholar

8. Sah JF, Balasubramanian S, Eckert RL, Rorke EA. Epigallocatechin-3-gallate inhibits epidermal growth factor receptor signaling pathway. Evidence for direct inhibition of ERK1/2 and AKT kinases. J Biol Chem. 2004;279:12755-12762. 
9. Gupta S Hastak K Ahmad N Lewin JS Mukhtar H Inhibition of prostate carcinogenesis in TRAMP mice by oral infusion of green tea polyphenols Proc Natl Acad Sci USA 200198103501035556964

$10.1073 /$ pnas. 171326098

10. Liang YC, Lin-Shiau SY, Chen CF, Lin JK. Inhibition of cyclin-dependent kinases 2 and 4 activities as well as induction of Cdk inhibitors p21 and p27 during growth arrest of human breast carcinoma cells by (-)epigallocatechin-3-gallate. J Cell Biochem. 1999;75:1-12.

View Article Google Scholar

11. Vayalil PK, Katiyar SK. Treatment of epigallocatechin-3-gallate inhibits matrix metalloproteinases-2 and -9 via inhibition of activation of mitogen-activated protein kinases, c-jun and NF-kappaB in human prostate carcinoma DU-145 cells. Prostate. 2004;59:33-42.

View Article Google Scholar

12. Zhang Q, Tang X, Lu Q, Zhang Z, Rao J, Le AD. Green tea extract and (-)-epigallocatechin-3-gallate inhibit hypoxia- and serum-induced HIF-1alpha protein accumulation and VEGF expression in human cervical carcinoma and hepatoma cells. Mol Cancer Ther. 2006;5:1227-1238.

View Article Google Scholar

13. Wu AH, Yu MC, Tseng CC, Hankin J, Pike MC. Green tea and risk of breast cancer in Asian Americans. Intl J Cancer. 2003;106:574-579.

View Article Google Scholar

14. Folkman J. Tumor angiogenesis: therapeutic implications. N Engl J Med. 1971;285:1182-.

View Article Google Scholar

15. Ferrara N, Gerber HP, LeCouter J. The biological properties of VEGF and its receptors. Nat Med. 2003;9:669676.

View Article Google Scholar

16. Brown NS Bicknell R Hypoxia and oxidative stress in breast cancer. Oxidative stress: its effects on the growth, metastatic potential and response to therapy of breast cancer Breast Cancer Res 20013323 $32713869610.1186 / \mathrm{bcr} 315$

17. Young E Miele L Tucker KB Min Huang M Wells J Gu JW SU11248, a selective tyrosine kinases inhibitor suppresses breast tumor angiogenesis and growth via targeting both tumor vasculature and breast cancer cells Cancer Biol Ther 2010107037113230514 10.4161/cbt.10.7.12904

18. Sirotnak FM, Otter GM, Schmid FA. Markedly improved efficacy of edatrexate compared to methotrexate in a high-dose regimen with leucovorin rescue against metastatic murine solid tumor. Cancer Res. 1993;53:587591.

View Article Google Scholar

19. Gu JW, Fortepiani L, Reckelhoff JF, Adair TH, Wang J, Hall JE. Increased expression of vascular endothelial growth factor and capillary density in hearts of spontaneously hypertensive rats. Microcirculation. 2004;11:689-697.

View Article Google Scholar

20. Gu JW, Bailey AP, Sartin A, Makey I, Brady AL. Ethanol stimulates tumor progression and expression of vascular endothelial growth factor in chick embryos. Cancer. 2005;103:422-431.

View Article Google Scholar

21. Gu JW, Young E, Busby B, Covington J, Tan W, Johnson JW. Oral Administration of Pyrrolidine Dithiocarbamate (PDTC) Inhibits VEGF Expression, Tumor Angiogenesis, and Growth of Breast Cancer in Female Mice. Cancer Biol Ther. 2009;8:514-521.

View Article Google Scholar

22. Folkman J. Angiogenesis and breast cancer. J Clin Oncol. 1994;12:441-.

View Article Google Scholar

23. Ullmann U, Haller J, Decourt JP, Girault J, Richard-Caudron AS, Pineau B. A single ascending dose study of epigallocatechin gallate in healthy volunteers. J Int Med Res. 2003;31:88-101.

View Article Google Scholar 
24. Nagle D, Ferreira D, Zhou YD. Epigallocatechin-3-gallate (EGCG): chemical and biomedical perspectives. J Phytochemistry. 2006;67:1849-1855.

View Article $\underline{\text { Google Scholar }}$

25. Toyokuni S, Okamoto K, Yodoi J, Hiai H. Persistent oxidative stress in cancer. FEBS Lett. 1995;358:1-3. View Article Google Scholar

26. Szatrowski TP, Nathan CF. Production of large amounts of hydrogen peroxide by human tumor cells. Cancer Res. 1991;51:974-998.

View Article Google Scholar

27. Kundu N, Zhang S, Fulton AM. Sublethal oxidative stress inhibits tumor cell adhesion and enhances experimental metastasis of murine mammary carcinoma. Clin Exp Metastasis. 1995;13:16-22.

View Article Google Scholar

28. Spitz DR, Sim JE, Ridnour LA, Galoforo SS, Lee YJ. Glucose deprivation-induced oxidative stress in human tumor cells. A fundamental defect in metabolism?. Ann N Y Acad Sci. 2000;899:439-462.

View Article Google Scholar

29. Foekens JA, Peters HA, Grebenchtchikov N, Look MP, Meijer-van Gelder ME, Geurts-Moespot A. High tumor levels of vascular endothelial growth factor predict poor response to systemic therapy in advanced breast cancer. Cancer Res. 2001;61:5407-5414.

View Article Google Scholar

30. Dales JP, Garcia S, Meunier-Carpentier S, Andrac-Meyer L, Haddad O, Lavaut MN. Overexpression of hypoxiainducible factor HIF-1alpha predicts early relapse in breast cancer: retrospective study in a series of 745 patients. Int J Cancer. 2005;116:734-739.

View Article Google Scholar

31. Jung YD Kim MS Shin BA Chay KO Ahn BW Liu W EGCG, major component of green tea, inhibits tumor growth by inhibiting VEGF production in human colon carcinoma cells Br J Cancer 200184844 8502363808 10.1054/bjoc.2000.1691

32. Shimizu M, Shirakami Y, Sakai H, Yasuda Y, Kubota M, Adachi S. (-)-Epigallocatechin gallate inhibits growth and activation of the VEGF/VEGFR axis in human colorectal cancer cells. Chem Biol Interact. 2010;185:247252.

View Article Google Scholar

33. Fujiki H, Suganuma M, Okabe S, Sueoka N, Komori A, Sueoka E. Cancer inhibition by green tea. Mutat Res. 1998;402:307-310.

View Article Google Scholar

34. Singh BN Shankar S Srivastava RK Green tea catechin, epigallocatechin-3-gallate (EGCG): mechanisms, perspective and clinical applications Biochem Pharmacol 201182180718214082721 10.1016/j.bcp.2011.07.093

35. Zhang G Wang Y Zhang Y Wan X Li J Kiu K Anti-cancer activities of tea epigallocatechin-3-gallate in breast cancer patients under radiotherapy Curr Mol Med 2012121631763305796 $10.2174 / 156652412798889063$

36. Lowery AJ, Sweeney KJ, Molloy AP, Hennessy E, Curran C, Kerin MJ. The effects of menopause and hysterectomy on systemic vascular endothelial growth factor in women undergoing surgery for breast cancer. BMC Cancer. 2008;8:927-

View Article Google Scholar

37. Gu JW Manning RD Jr Young E Shparago M Sartin B Bailey AP Vascular endothelial growth factor receptor inhibitor enhances dietary salt-induced hypertension in Sprague-Dawley (SD) rats Am J Physiol Regul Integr Comp Physiol 2009297 R142 R1482711701 10.1152/ajpregu.90972.2008

38. Chen HX, Cleck JN. Adverse effects of anti-cancer agents that target the VEGF pathway. Nat Rev Clin Oncol. 2009;6:465-477.

View Article $\underline{\text { Google Scholar }}$

39. Choueiri TK, Mayer EL, Je Y, Rosenberg JE, Nguyen PL, Azzi GR. Congestive heart failure risk in patients with breast cancer treated with bevacizumab. J Clin Oncol. 2011;29:632-638.

View Article Google Scholar 
40. An MM, Zou Z, Shen H, Liu P, Chen ML, Cao YB. Incidence and risk of significantly raised blood pressure in cancer patients treated with bevacizumab: an updated meta-analysis. Eur J Clin Pharmacol. 2010;66:813-821. View Article Google Scholar

41. Geiger-Gritsch S Stollenwerk B Miksad R Guba B Wild C Siebert U Safety of bevacizumab in patients with advanced cancer: a meta-analysis of randomized controlled trials Oncologist 201015117911913227908 10.1634/theoncologist.2009-0155

42. Criscitilello C, Metzger-Filho O, Saini KS, de Castro Jr G, Diaz M, Gerche AL. Targeted therapies in breast cancer: are heart and vessels also being targeted?. Breast Cancer Research. 2012;14:209-.

View Article Google Scholar 